\title{
Geophysical Constraints on Washington Convergent Margin Structure
}

\author{
CAROL Finn
}

\author{
U.S. Geological Survey, Denver, Colorado
}

\begin{abstract}
Gravity and magnetic maps of western Washington reveal the lateral structure and fabric of the Washington Coast Range, Puget Basin, and southern Washington Cascade Range. The magnetic and gravity maps show large amplitude positive anomalies associated with the shallow but largely buried section of Washington Coast Range mafic rocks which are separated by negative anomalies over deep sedimentary basins. The positive anomalies indicate that the Coast Range mafic basement extends farther east than previously thought, at least as far east as the longitude of Seattle. Linear and steep gravity and magnetic gradients indicate many unmapped, often buried faults in the Washington Coast Range Province. Magnetic highs are also associated with mapped batholiths in the Cascade arc. Several magnetic highs observed east of the Coast Range rocks and west of these batholiths may be associated with buried Tertiary plutons or ophiolites. Two-dimensional gravity and magnetic modeling constrained with geological and other geophysical data indicate that the Coast Range Province rocks are about $1 \mathrm{~km}$ thick at the coast, thickening to as much as $30 \mathrm{~km}$ near their postulated eastern edge. A maximum boundary on the average density of the upper $15-20 \mathrm{~km}$ of the rocks that compose the Coast Range Province of $2920 \mathrm{~kg} / \mathrm{m}^{3}$ was established by the modeling, suggesting a composition largely of basalt and gabbro with little interbedded sediments. Under these rocks may be mantle or a subduction complex composed of dense mafic, ultramafic, and sedimentary rocks like that proposed to underlie Vancouver Island. Previous gravity models of the Washington margin include lower densities for the proposed subduction complex than for Vancouver Island, suggesting a lower component of mafic and ultramafic rocks than the rocks underlying Vancouver Island. However, my Washington model requires that the proposed subduction complex be more dense than the trench sediments and, therefore, that material denser than sediments be incorporated within it. The absence of continental mantle and the modeled wedge shape of the Coast Range Province upper crust suggest that erosion of the bottom of the overriding plate by subduction processes may have occurred.
\end{abstract}

\section{INTRODUCTION}

In order to evaluate hidden geothermal and other resources in the Cascade Range, more information on its tectonic setting is necessary. The localization of the Cascade volcanos, and associated geothermal systems, results from subduction related processes as well as from the structure and tectonics in the overriding plate [e.g., Guffanti and Weaver, 1988; Blakely and Jachens, this issue]. Accreted terrane boundaries may play a role in localizing volcanos [Stanley et al., 1987]. However, the cover of water, trees, sediments, and young volcaniclastic rocks makes it difficult to map the basement rocks and structures of western Washington that may help to localize geothermal resources.

Associated with the continental margin of western Washington, are distinct gravity and magnetic anomalies which reflect wide variations in density and magnetization contrasts that yield new information on subsurface structure. The major objective of this paper is to interpret gravity and magnetic maps and a $2 \frac{1}{3}$-dimensional gravity and magnetic model across the margin, concomitantly with other geophysical and geological information in order to determine the lateral and vertical extent of the Washington Coast Range accreted terrane and buried plutons. Comparison of the maps and model with other studies from Oregon and Vancouver Island, Canada, yields an integrated interpretation of the subsurface structure of the Pacific Northwest.

The Pacific Northwest is a zone of oblique convergence between the Juan de Fuca and North American plates at a rate of about $4.2 \mathrm{~cm} / \mathrm{yr}$ in the direction $N 50^{\circ} \mathrm{E}$ [Riddihough,

This paper is not subject to U.S. copyright. Published in 1990 by the American Geophysical Union.

Puper number $90 \mathrm{JB} 01425$.
1977, 1984]. Sediments, ocean ridges, seamounts, and island arcs transported by the subducting plate have collided with, and been subducted or accreted to, the North American plate.

Seismic refraction and reflection work [Shor et al., 1968; McClain and Taber, 1984; McClain, 1981; Snavely, 1987] has delineated the crustal structure of the subducting Juan de Fuca plate. In the offshore Cascadia basin (Figure 1), marine sediments averaging $500 \mathrm{~m}$ thick are underlain by marine basalts $5 \mathrm{~km}$ thick; depth to the Moho is about $10 \mathrm{~km}$. The continental shelf and slope are underlain by as much as 13 $\mathrm{km}$ of marine and continental sediments, some of which are highly deformed [Shor et al., 1968; McClain, 1981; Snavely, 1987].

The seismic refraction model of Taber and Lewis [1986] shows that the dip of the Juan de Fuca plate increases from $0.6^{\circ}$ under the Cascadia Basin [Shor et al., 1968; McClain, 1981; McClain and Taber, 1984] to $9^{\circ}$ about $110 \mathrm{~km}$ offshore. Crosson and Owens [1987] and Weaver and Baker [1988] use the distribution of earthquake hypocenters inferred to lie within the Juan de Fuca plate to interpret its southeast dip along an east-west section of $11^{\circ} \pm 2^{\circ}$ [Weaver and Baker, 1988 ] near the coast increasing to $20^{\circ}-25^{\circ}$ [Weaver and Baker, 1988; Crosson and Owens, 1987] at the longitude of central Puget Sound.

Interpretation of the dip of the Juan de Fuca plate east of the longitude of Puget Sound is constrained by teleseismic $P$ wave residuals [Michaelson and Weaver, 1986; Rasmussen and Humphreys, 1988], which indicate a plate dipping greater than $45^{\circ}$, probably close to $60^{\circ}$; interpretation of its maximum dip is not constrained by the data. The thickness of the Juan de Fuca plate cannot be determined from the teleseismic data because the block thickness used in the 

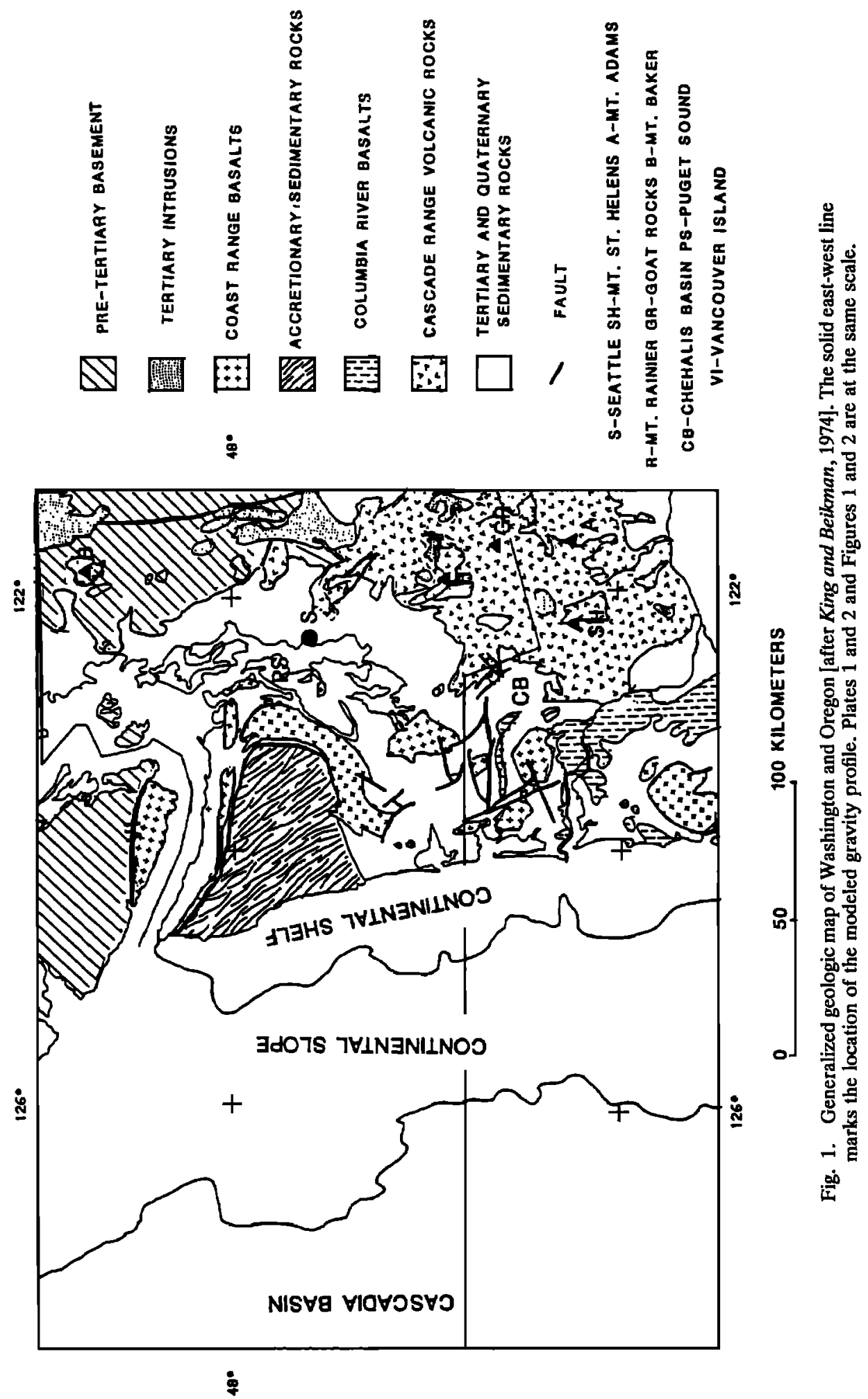
velocity model is $50 \mathrm{~km}$, about that of the plate [Michaelson and Weaver, 1986]. However, the oceanic lithospheric thickness can be determined from its age [e.g., Turcotte and Schubert, 1982]. I calculated the thickness of the Juan de Fuca plate, which is $8 \mathrm{~m} . \mathrm{y}$. old as it starts to subduct [Connard et al., 1984], to be about $35 \mathrm{~km}$.

The geology (Figure 1) of southwest Washington and surrounding areas reflects the results of subduction. Several key provinces will be discussed in detail:

1. The Coast Range Province is underlain by thick, Paleocene to middle Eocene mostly submarine basalts called the Siletz River Volcanics in Oregon [Snavely and Baldwin, 1948], the Crescent Formation in Washington, and Metchosin Volcanics on southern Vancouver Island [Massey, 1986]. These basalts and the upper crust of the Coast Range province collectively will be referred to as the Coast Range mafic rocks throughout this paper. Three models have been invoked to explain the origin of the Coast Range mafic rocks: (1) They were part of a seamount complex erupted on oceanic crust that was accreted to the continent by the middle Eocene [Duncan, 1982], (2) the Coast Range mafic rocks were erupted along leaky fractures and transforms during changes in spreading directions near the Yellowstone hot spot, and (3) they were erupted in the wake of oblique rifting of North America [Wells et al., 1984; Clowes et al., 1987; Snavely, 1987]. Any of these models would allow for great thicknesses of basalts and gabbros in the Coast Range; thickness as much as $9-20 \mathrm{~km}$ has been estimated from geologic mapping in the Olympic Peninsula [e.g., Tabor and Cady, 1978; Massey, 1986] or from analogy with ocean island basalt thicknesses in Hawaii [e.g., Zucca et al., 1982].

After accretion of the Coast Range Province, the Yachats [Snavely and MacLeod, 1974] and Tillamook [Wells et al., 1984] basalts were erupted in Oregon, and the Goble, Grays River, and Northcraft [Wells, 1981, 1989; Walsh et al., 1987] basalts were erupted in Washington.

Deep structure of the Coast Range Province is not well known. Seismic refraction data in the area [Taber and Lewis, 1986] do not detect a Moho in the North American plate under the Coast Range. If the structure of the Coast Range resembles that found under southern Vancouver Island [Clowes et al., 1987] and Oregon [Keach et al., 1989; Wannamaker et al., 1989], then the Coast Range mafic rocks are underlain by a modern subduction complex consisting of underthrust sediments and offscraped oceanic crust with no continental mantle. Magnetotelluric profiles from west central Washington [Stanley et al., 1987, 1988] indicate that the Coast Range mafic rocks increase in thickness eastward from about $3 \mathrm{~km}$ to as much as $30 \mathrm{~km}$ and may be underlain by a subduction complex sedimentary rocks, like those found in the Olympic Peninsula, and subducted sediments. Seismic reflection and refraction data [Clowes et al., 1987; Spence et al., 1985] indicate that Olympic Peninsula sedimentary rocks and subducting sediments underlie the Coast Range basalts on Vancouver Island.

2. The Puget Lowlands-Willamette Valley is a discontinuous set of basins extending from Puget Sound to southern Oregon. The province is underlain by continental and marine sediments as well as by volcaniclastic rocks [Armentrout and Suek, 1985]. In Washington, the province is represented by the Grays Harbor, Astoria, Chehalis, and Puget Sound basins. For the most part, the thickness of the sedimentary and volcanic section is unknown. In the Che- halis Basin, a seismic reflection survey indicates a thickness of about $6 \mathrm{~km}$ for the sedimentary section, underlain by Coast Range mafic rocks [Ise, 1985]. In Oregon, seismic reflection data show $4-5 \mathrm{~km}$ of sediments within the Willamette Valley, also underlain by Coast Range rocks [Keach et al., 1989].

3. The Cascade Range Province is a Tertiary to recent magmatic arc related to subduction of the Juan de Fuca plate. In southwest Washington, Mount St. Helens, Mount Rainier, Mount Adams, and Goat Rocks Volcano are andesitic stratocones built upon upper Eocene and younger volcanogenic rocks. Goat Rocks Volcano is the only stratovolcano including rocks older than $1 \mathrm{~m} . y$. [Sherrod and Smith, this issue]. Although the rocks range in composition from basalt to rhyolite, basalt is the dominant rock type in the southern Washington Cascades. Shallow intrusions underlie Goat Rocks Volcano [Williams and Finn, 1987], Mount St. Helens [Williams et al., 1987], and Mount Rainier [Williams and Finn, 1985]. Indian Heaven volcanic field, located between Mount St. Helens and Mount Adams, has the largest volume of Quaternary mafic rocks in Washington, half of which was erupted over the last $1 \mathrm{~m} . \mathrm{y}$. [Sherrod and Smith, this issue].

Sediments inferred to be part of a possibly Cretaceous age, accreted marine forearc basin or accretionary prism may underlie the southern Washington Cascades at depths of $1-10 \mathrm{~km}$ and with thicknesses as much as $15 \mathrm{~km}$ [Stanley et al., 1987, 1988]. The coincidence of Mount Rainier, Mount St. Helens, and Mount Adams with the edge of this proposed accretionary prism suggests that the edge may help to localize the volcanos [Stanley et al., 1987, 1988].

Moho depth under the Washington Cascades is unknown, but may be $40 \mathrm{~km}$ as indicated by a refraction survey of the Oregon Cascades [Leaver et al. 1984]. The thickness of the continental lithosphere is also unknown but based on thermal arguments may be between 80 and $100 \mathrm{~km}$ [e.g., Turcotte and Schubert, 1982].

\section{Gravity and Magnetic Data}

Digital gravity data [Finn, 1984] were used to compile the gravity map of the study area (Plate 1, complete Bouguer on land, free-air over the ocean). The land data were reduced at a density of $2670 \mathrm{~kg} / \mathrm{m}^{3}$, roughly the average density of terrain in the area. The gravity field offshore is relatively flat except for a free-air gravity high (A on Plate 1) superimposed on lows (marked with B and C on Plate 1) associated with the sediment-filled trench and geometry of the oceanic crust as it subducts. The high (anomaly A, Plate 1) is due to the density contrast between dense, deformed sediments within the trench and adjacent, less dense sediments [Couch and Braman, 1979; McClain, 1981].

Major Bouguer gravity highs (D-G on Plate 1) within the onshore part of the study area are associated with the Coast Range Province in Washington and Vancouver Island. One of the sources of these gravity highs is probably the relatively high-density Coast Range mafic rocks. The overall Const Range gravity high is composed of several separate highs (D-G on Plate 1) bounded by steep gravity gradients. The sinuous, steep, generally north-south trending gravity gradient at about $123^{\circ}$ longitude has been inferred to indicate the eastern edge of the Coast Range mafic rocks [e.g., Stuart, 1961; Simpson et al., 1986]. 


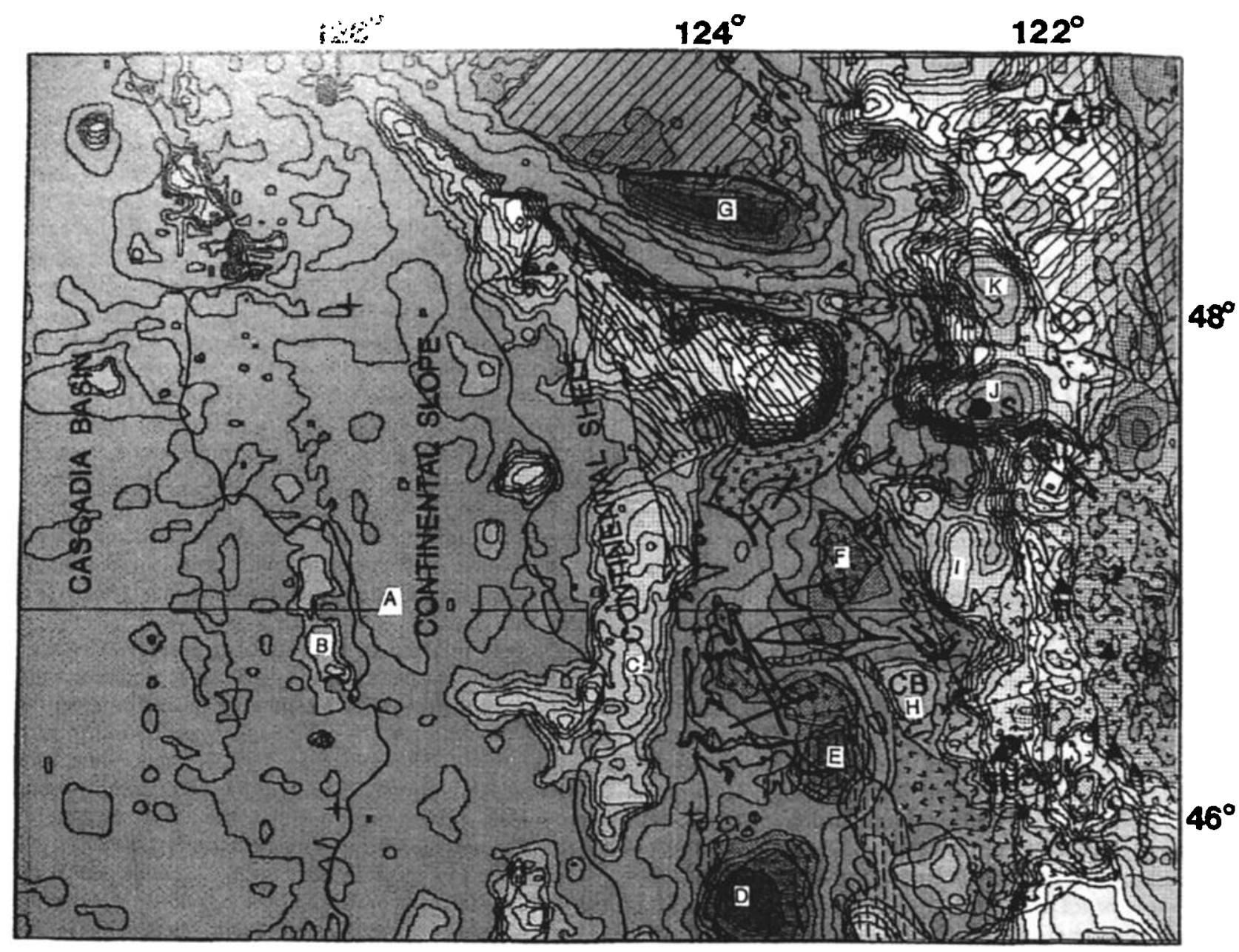

$0 \quad 50$

100 KILOMETERS

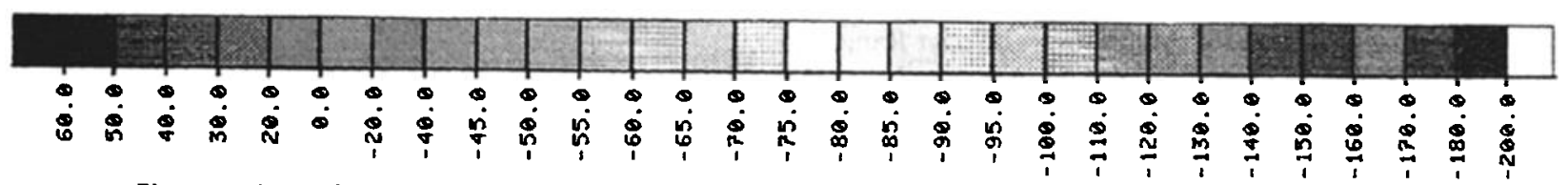

Plate 1. Map of the complete Bouguer anomaly of Washington in milliGals with a Bouguer reduction density of 2670 $\mathrm{kg} / \mathrm{m}^{3}$ overlain by the geologic map shown on Figure 1. The solid east-west line marks the location of the modeled profile. The triangles mark the major Cascade volcanos. The letters refer to anomalies mentioned in the text.

Associated with the major high topographic areas (the Olympic Mountains and the Cascade Range (marked by triangles, Plate 1)) are Bouguer gravity lows, which probably reflect the relatively low-density rocks that provide isostatic compensation for the mountains. Large gravity lows over the Puget-Willamette Lowland (marked $\mathrm{H}-\mathrm{K}$ on Plate 1) indicate basins with great (6 km, possibly as much as $12 \mathrm{~km}$ ) thicknesses of sediments and volcaniclastic rocks [Hall and Orhberg, 1974]. The fact that steep gravity gradients surround these gravity lows suggests that the basins are fault bounded.

Aeromagnetic maps are particularly useful in studying the subsurface structure of the Pacific Northwest. Most positive magnetic anomalies are caused by normally magnetized rocks, more magnetic than the adjacent units. Negative magnetic anomalies can be caused by reversely magnetized rocks or rocks with lower intensities than the surrounding ones. Most of the surficial rocks in the study area have predominantly normal magnetizations, although there are some reversed rocks in each unit [e.g., Wells and Coe, 1985; Bates et al., 1982; Beck, 1980]. Exceptions are the Grays River and Tillamook volcanics [Wells and Coe, 1985; Magill et al., 1981].

The onshore magnetic data used to make Plate 2 were extracted from a grid used to compile the North American magnetic map [Committee for the Magnetic Anomaly Map of North America. 1987], which is composed of separate surveys digitized at a scale of 1:1,000,000 and hand merged with no analytic continuation. The offshore magnetic data are from widely spaced ship track data IConnard et 

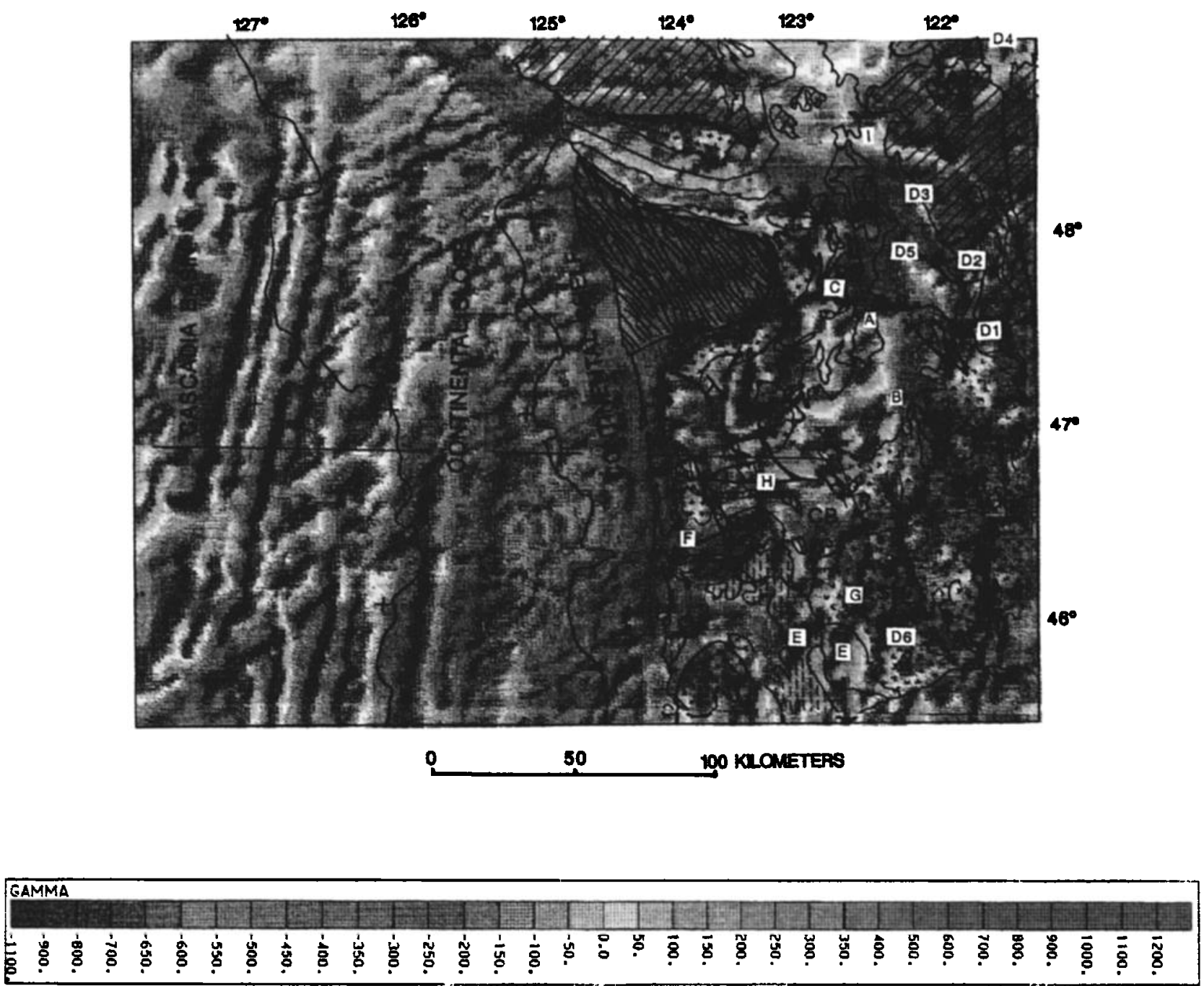

Plate 2. Shaded relief map of the aeromagnetic anomaly of Washington in nTesla [from Committee for the Mugnetic Anomaly Map of North America, 1987; Connard et al., 1984] overlain by the geologic map shown on Figure 1. The solid east-west line marks the location of the modeled profile. The triangles mark the location of the major Cascade volcanos. The letters refer to anomalies mentioned in the text.

al.,1984]. The onshore and offshore surveys were spliced together to make one of the first complete aeromagnetic maps of the region shown as a shaded relief color map, illuminated from the southeast in Plate 2.

The offshore part of the map shows the magnetic stripes associated with reversed and normally polarized portions of seafloor. As the Juan de Fuca plate begins to subduct beneath the continental shelf and slope (Plate 2), these anomalies attenuate, forming a magnetic quiet zone. This quiet zone is characteristic of many convergent margins in the Pacific. Controversy exists as to whether these quiet zones are due primarily to the increased distance of magnetic subducting plates from the magnetometer [e.g., Grow, 1973; Oshima and Kasuga, 1988] or to hydrothermal alteration of the magnetic subducting oceanic crust [e.g., Scheidegger. 1984]. In a following section, I will discuss a model of the magnetic data offshore which addresses this issue.

A belt of magnetic highs west of the longitude of Mount St. Helens and Seattle (SH and S, respectively, on Plate 2) extends partly over the Puget Lowland. The high correlates in places with exposed and unexposed portions of the Coast
Range mafic rocks in southern Vancouver Island, as delineated by geologic mapping [e.g., Massey, 1986], gravity (Plate 1) and seismic reflection data [Clowes et al., 1987], and in southern Washington, as delineated by geologic mapping [e.g., King and Beikman, 1974: Wells, 1981, 1989] and magnetotelluric data [Stanley et al., 1987]. This correlation suggests that the Coast Range mafic rocks are the source of the high. The steep gradients of the edge of the magnetic high also suggest that its source is shallow.

My interpreted eastern boundary of the shallowest section of Coast Range mafic rocks is farther east than that proposed by others [e.g., Stuart, 1961; Simpson et al., 1986], an interpretation based on the gravity data alone. The boundary delineated by the magnetic data roughly corresponds to a steep, north-south trending gravity gradient on the gravity map (the longitude of Mount St. Helens and Seattle, SH and $S$, respectively, on Plate 1). The Coast Range mafic rocks may extend even farther to the east but are probably not shallow. In central Washington, the steep, north-south trending magnetic gradients (south of Seattle, $S$ on Plate 2) that delineate the edge of the Coast Range magnetic high are 


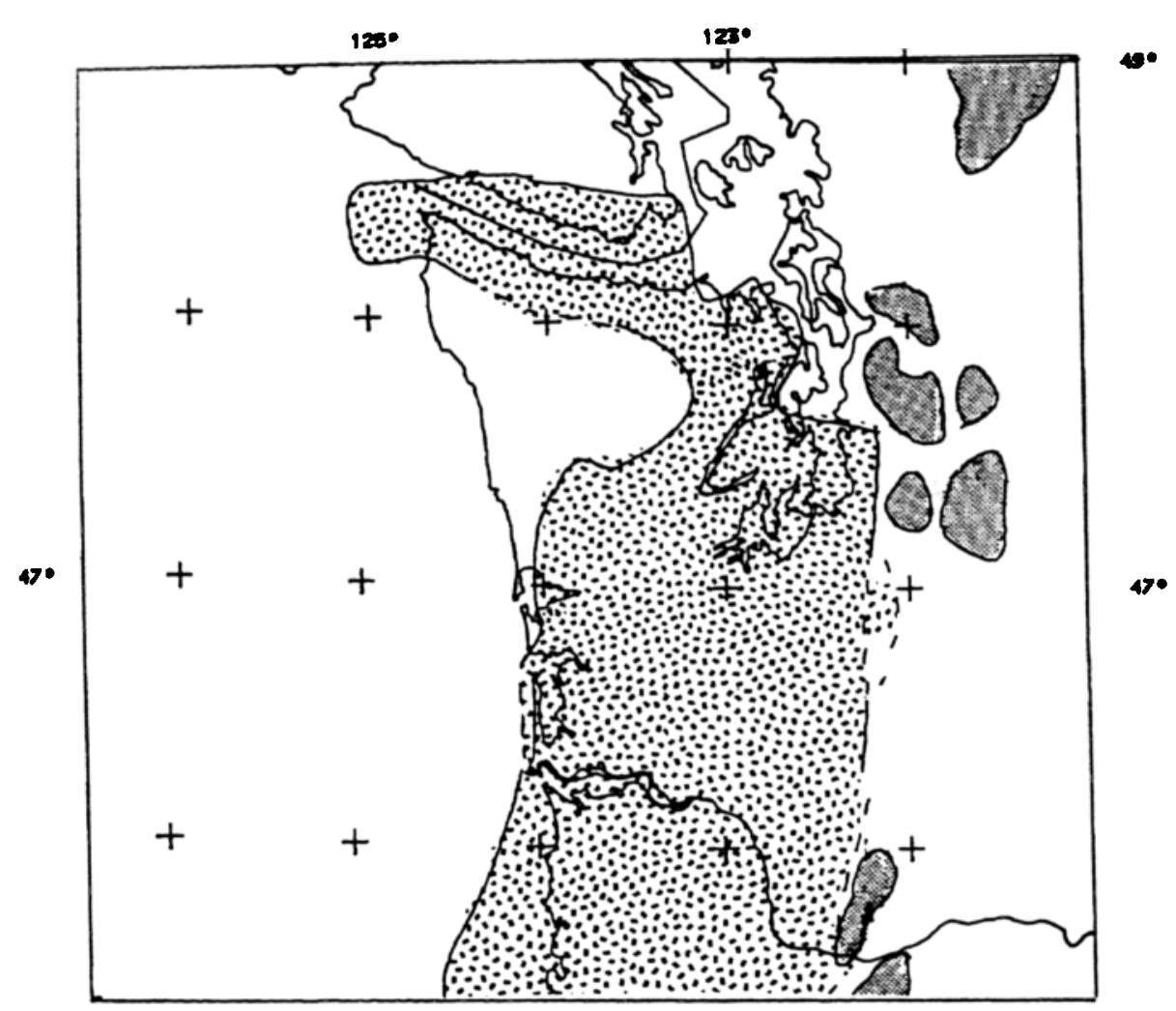

Fig. 2. Minimum lateral extent of Coast Range mafic rocks and plutons interpreted from the gravity (Plate 1) and magnetic maps (Plate 2).

very straight, suggesting that they reflect faults. A steep, east-west trending magnetic gradient (marked $\mathrm{C}$ on Plate 2) corresponds to a mapped fault [Snavely et al., 1958]. The magnetic gradient also corresponds to the steep gravity gradient marking the southern boundary of gravity low $\mathrm{J}$ on Plate 1.

Some of the magnetic highs (anomalies marked D1-D6 on Plate 2) east of the Coast Range high are related to mapped, large plutons [e.g., Smith, in press; Walsh et al., 1987] such as the Snoqualamie batholith (D1, Plate 2) [Smith, 1990; Walsh et al., 1987], Chilliwack (D4, Plate 2) [Smith, 1990], and Woods Creek (D2, Plate 2) [Wetten et al., 1980]. Small, low-amplitude magnetic highs east of the Olympic Mountains (D3 and D5, Plate 2), may correspond to buried plutons or ophiolites. In northem Oregon and southern Washington, several large highs (marked E on Plate 2) are associated with areas where magnetic Columbia River basalts overlie Coast Range basalts.

Magnetic lows within the Coast Range magnetic high are sometimes related, in southwest Washington, to predominantly reversed rocks of the Grays River (marked F and $G$ on Plate 2) and Tillamook volcanics of northwest Oregon [Magill et al., 1981; Wells and Coe, 1985]. Lows also indicate areas where the magnetic Coast Range mafic rocks are covered by thick nonmagnetic sediments. North of the magnetic low over the Chehalis Basin is a lip of the Coast Range magnetic high, bounded on the west by a steep, northwest trending magnetic boundary (marked $\mathrm{H}$ on Plate 2). The gravity low ( $H$ on Plate 1) associated with the Chehalis Basin extends farther to the north than does the magnetic low (CB, Plate 2). The greater sensitivity of magnetic data to shallow features and the absence of a gravity high suggests that only a thin lip of the Coast Range mafic rocks extends into the Chehalis Basin. If so, the northwest trending magnetic gradient ( $\mathrm{H}$ on Plate 2 ) may delineate a thrust fault.

In northern Washington, a curvilinear belt of magnetic highs, starting on Vancouver Island and extending east, is associated with the Fildago ophiolite (I, Plate 2) [Wetten et al., 1980]. The small, low-amplitude highs southeast of anomaly B in Plate 2 may be associated with the Coast Range mafic rocks or batholiths possibly delineated by magnetotelluric data [Stanley et al., 1987]. Magnetic highs in Washington are also caused by magnetic volcanic rocks that compose the topography of Mount St. Helens and Mount Adams, intrusions like that underlying Goat Rocks Volcano [Williams and Finn, 1987] and to the andesite and basalt flows [see Walsh et al., 1987] of Indian Heaven. The great thickness of nonmagnetic sediments in the Olympic Peninsula are associated with a magnetic low.

Figure 2 summarizes the discussion above and shows the minimum lateral extent of Coast Range mafic rocks and plutons interpreted from the geologic, gravity, and magnetic maps. The Coast Range mafic rocks are interpreted to 
underlie most of western Washington and comprise a fairly continuous block. The Olympic Peninsula melange is probably not underlain by Coast Range mafic rocks, but rather rests directly on top of the Juan de Fuca plate [Taber and Smith, 1985]. Plutons in south and central Washington seem to lie along the edge of the Coast Range mafic rocks, sugesting that they have filled the suture zone between the Coest Range and preaccretion crust in the Cascades [Stanley et al., this issue]. Geochemical data from southern Washington [Evarts et al., 1987; Leeman et al., 1989] and geophysical data [Stanley et al., this issue] suggest that the southern Washington Cascade Range is underlain by oceanic mafic rocks but cannot discriminate between Coast Range mafic rocks and other mafic crust. It is also possible that the postulated intrusions (Figure 2), as well as those in the High Cascades (not shown), may have intruded the Coast Range mafic rocks thereby obscuring their geophysical signature and eastern boundary.

\section{Modeling}

The qualitative interpretation presented above gives information on the lateral extent of the sources of observed gravity and magnetic anomalies. In order to determine the structures, densities, and magnetizations that produce the observed gravity and magnetic anomalies, I used a $2 \frac{1}{2}$ dimensional forward and inverse gravity and magnetic modeling program [Webring, 1985]. The program uses profiles of gravity and magnetic observations (profile location on Figure 1 and Plates 1 and 2) and a starting model consisting of body corners and density and magnetization contrasts. The program then adjusts the starting model so that its gravitational and magnetic attraction fits the profiles of observed data. The evolution of the final model is controlled by allowing only a few parameters to vary in each modeling attempt and constraining those parameters to a specified range. Where the structures are well constrained (like that of the Juan de Fuca plate, for example), I did not allow the body geometry to change, forcing the program to modify the starting physical properties only. I based the geometry of the starting model on the mapped geology, magnetotelluric, earthquake locations, and seismic tomography, reflection and refraction data described above.

Average values given in the literature for certain rock types [e.g., Telford et al., 1976], measurements from hand samples, and well data guided the selection of density and magnetizations for the starting model. Densities were also inferred from measured seismic refraction velocities where available; the relation between seismic wave velocities and density is approximately linear but densities can vary by as much as $\pm 200 \mathrm{~kg} / \mathrm{m}^{3}$ for a single velocity [Nafe and Drake, 1957]. Hand sample measurements of the Crescent basalts show that they range in density from 2200 to $2950 \mathrm{~kg} / \mathrm{m}^{3}$ and have a mean of $2700 \mathrm{~kg} / \mathrm{m}^{3}$. Bromery and Snavely [1964] found the densities of samples from the Siletz River volcanics in Oregon (correlative to the Crescent basalts) to range from 2360 to $3020 \mathrm{~kg} / \mathrm{m}^{3}$ and average $2800 \mathrm{~kg} / \mathrm{m}^{3}$, similar to my results. In all cases, magnetizations of modeled bodies are assumed to be in the Earth's present field direction of inclination of $69^{\circ}$, declination of $19^{\circ}$, and intensity of 55,670 nT [Peddie, 1987]. This assumption is reasonable because the age of the rocks along the profile modeled with potentially high remanence (the volcanic rocks) are post-Eocene [e.g., Walsh et al., 1987]. Cox and Doell [1960] proposed that post-Eocene rocks without tectonic rotation have magnetization vectors effectively collinear with the Earth's present field direction. In southwest Washington, tectonic rotation is small to moderate [Wells and Coe, 1985]. My measured average total magnetization for the Crescent basalts samples has a declination of $17.6^{\circ}$, an inclination of $70.4^{\circ}$, and an intensity of $2.75 \mathrm{~A} / \mathrm{m}$, roughly aligned with Earth's present field. Structures lying deeper than about $20-25 \mathrm{~km}$ were assumed to be nonmagnetic. The short wavelength of the observed magnetic anomalies indicates that their sources are shallow.

A controversy in modeling gravity anomalies over subduction zones is the relative contribution of deep versus shallow sources. Some gravity models, for example, Grow [1973], Grow and Bowin [1975] and Segawa and Tomoda [1976], suggest that the density contrast between the subducting plate and the surrounding asthenosphere causes a significant gravity anomaly. Others, [Watts and Talwani, 1975; Couch and Woodcock, 1981; Fukao et al., 1989; Couch and Riddihough, 1990] show that density contrasts within the upper 50 $\mathrm{km}$ are the primary causes of the observed gravity anomalies. The gravity anomaly due to the part of the subducting Juan de Fuca plate deeper than $50 \mathrm{~km}$ (Figure 3) is small. Its amplitude is about $18 \mathrm{mGal}$ with a long half wavelength of $500 \mathrm{~km}$ [Finn, 1988]. Reducing the thickness of the model by eliminating the deep part of the subducting plate from the model changes the densities of the upper $50 \mathrm{~km}$ only slightly, indicating that the gravity data are not sensitive to the deep part of the subducting plate. In my model (Figure 3), I include the subducting plate because it is known to exist.

The assigned densities of the deep part of the subducting plate of $3300 \mathrm{~kg} / \mathrm{m}^{3}$ and of the asthenosphere of $3280 \mathrm{~kg} / \mathrm{m}^{3}$ in Figure 3 are based on theoretical petrological studies [Ahrens and Schubert, 1975; Grow, 1973; Grow and Bowin, 1975] of the density variation of inferred asthenospheric materials with depth and temperature. Lateral variations in asthenospheric densities, particularly under magmatic ares (where the density decreases because of high temperatures), have been proposed [Grow, 1973] but are unknown.

Inclusion of the subducting Juan de Fuca plate requires extension of the gravity profile east of the Cascade Range into the Columbia Plateau flood basalt province. I did not model the magnetic anomaly there because the plateau is not a focus of this study. The crustal structure and Moho depth are consistent with seismic refraction [Catchings and Mooney, 1988] and magnetotelluric (MT) data [Stanley, 1984]; the assigned densities are compatible with the refraction velocities [Catchings and Mooney, 1988].

To eliminate end effects, the starting model was continued with the layers shown at the ends of the section out to \pm 3000 $\mathrm{km}$. Perpendicular to the profile, the blocks were extended $\pm 100 \mathrm{~km}$.

Figure 3 shows the Washington model and its calculated and observed gravity and magnetic profiles. Figure 4 shows the upper $50 \mathrm{~km}$ of the model vertically exaggerated 3 times, with body numbers corresponding to those listed, along with densities and intensities of magnetization, in Table 1 . The absolute values of the listed densities and intensities of magnetization (Table 1) are somewhat arbitrary because the modeling determines relative values only.

Over the Cascadia Basin, the gravity field is flat and the modeled densities and thicknesses of the oceanic sediments 


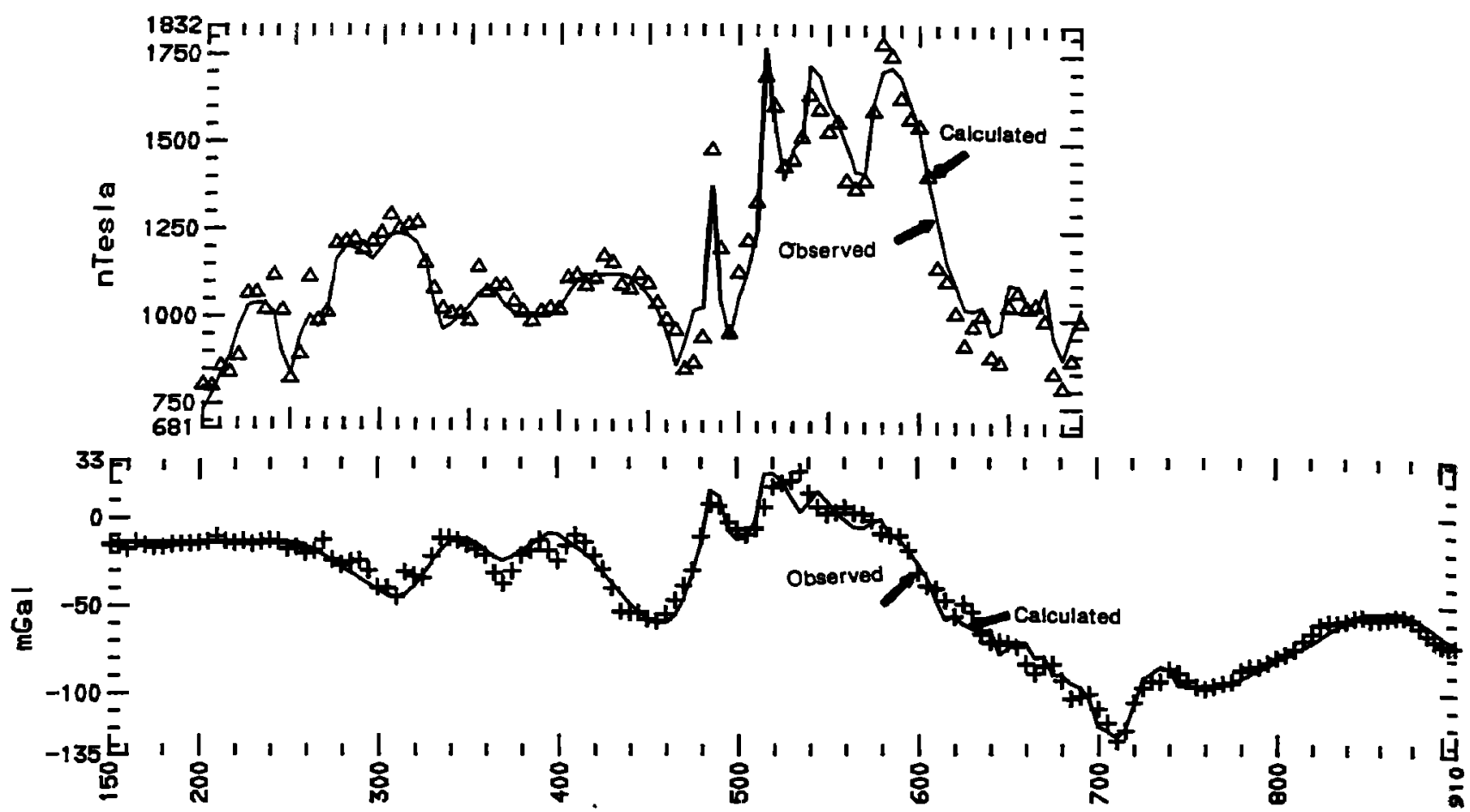

kl lometer



Fig. 3. Washington model. Results of the gravity and magnetic modeling for the profiles located on Plates 1 and 2. For each profile, the calculated (line) and observed (crosses for gravity; triangles for magnetic) anomalies (from Plates 1 and 2) are shown. Solid sections of the subducting oceanic crust indicate relatively positively magnetized blocks, uncolored sections negatively magnetized blocks. Densities $\left(\mathrm{kg} / \mathrm{m}^{3}\right)$ for mantle body are shown. Table 1 lists the densities and magnetizations for all bodies. 

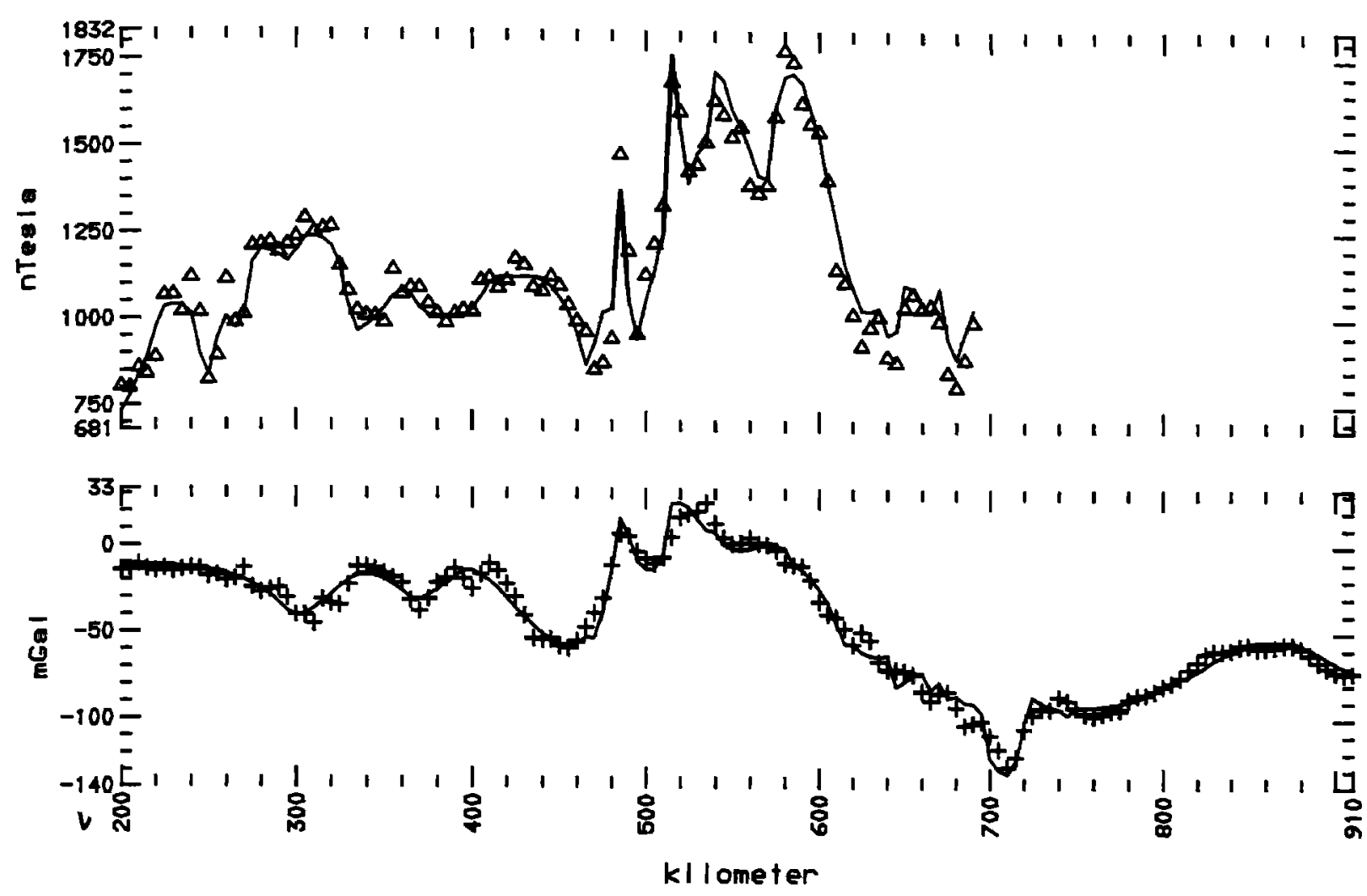

V.E. 3:1

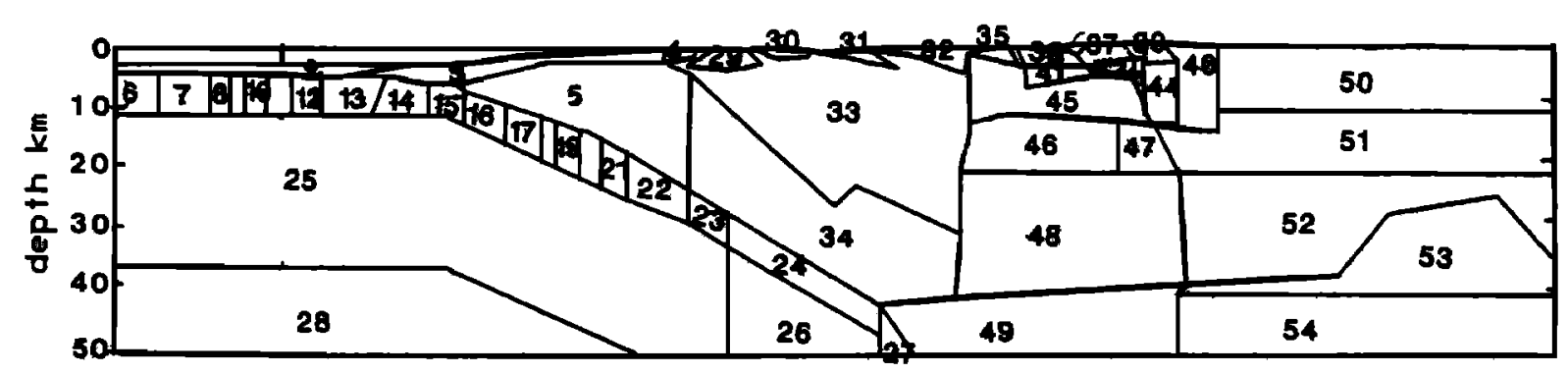

Fig. 4. A closeup of the upper $50 \mathrm{~km}$ of Figure 3 vertically exaggerated 3 times. Body numbers refer to those listed in Table 1.

(body $2,1880 \mathrm{~kg} / \mathrm{m}^{3}$ and $1 \mathrm{~km}$, respectively) and oceanic crust (bodies $6-24,2850 \mathrm{~kg} / \mathrm{m}^{3}$ and $6 \mathrm{~km}$, respectively) are consistent with expected values based on drilling in oceanic crust and seismic velocities [Shor et al., 1968].

Over the continental slope, a gravity high (Figure 3 ) is partly related to the density contrast between rocks within the trench (bodies $3\left(2530 \mathrm{~kg} / \mathrm{m}^{3}\right)$ and $\left.5\left(2700 \mathrm{~kg} / \mathrm{cm}^{3}\right)\right)$ and lower density sediments (body $2,1880 \mathrm{~kg} / \mathrm{m}^{3}$ ) in the Cascadia Basin and water (body $1,1030 \mathrm{~kg} / \mathrm{cm}^{3}$ ). McClain [1981] related the gravity high also to dense rocks within the trench that he interpreted to be deformed sediments, offscraped oceanic crust, or both. His modeled density of $2800 \mathrm{~kg} / \mathrm{m}^{3}$ is probably too high to represent sediments; he did not discuss the implications of this high density. The density of 2700 $\mathrm{kg} / \mathrm{m}^{3}$ obtained in my modeling is more reasonable but equivocal. Densities of the Hoh melange [Rau, 1973] that may represent the typical material in the continental slopes and shelf were measured in a well offshore of the Otympic Mountains and range from 2400 to $2550 \mathrm{~kg} / \mathrm{m}^{3}$ with porosjties ranging from 10 to $20 \%$ at about a $1 \mathrm{~km}$ depth (Pan American well P0141 (W. M. Phillips, oral communication, 1988)). An increase to $2700 \mathrm{~kg} / \mathrm{m}^{3}$ would not be unreasonable at greater depths. For mudstones with little or no porosity densities as high as $2700 \mathrm{~kg} / \mathrm{m}^{3}$ have been measured [Hamilton, 1978]. Additions of pieces of oceanic crust would also contribute to the high-density material required in the continental slopes and shelf.

Figure 3 shows varying amplitudes of the positive and negative magnetic anomalies offshore (magnetic stripes on Plate 2). Although the amplitudes of the anomalies decrease over the continental slope and shelf, they do not disappear. The anomalies were modeled with positively (solid blocks, 
TABLE 1. Body Number, Density and Magnetization for Gravity and Magnetic Model

\begin{tabular}{|c|c|c|}
\hline $\begin{array}{l}\text { Body Number } \\
\text { (Figure 4) }\end{array}$ & $\begin{array}{l}\text { Density, } \\
\mathrm{kg} / \mathrm{m}^{3}\end{array}$ & $\begin{array}{c}\text { Magnetization, } \\
\mathrm{A} / \mathrm{m}\end{array}$ \\
\hline 1 & 1030 & 0.0 \\
\hline 2 & 1880 & 0.0 \\
\hline 3 & 2530 & 0.0 \\
\hline 4 & 2380 & 0.0 \\
\hline 5 & 2750 & 0.0 \\
\hline 6 & 2850 & -1.61 \\
\hline 7 & 2850 & -0.59 \\
\hline 8 & 2850 & -2.59 \\
\hline 9 & 2850 & -0.70 \\
\hline 10 & 2850 & -1.24 \\
\hline 11 & 2850 & 1.51 \\
\hline 12 & 2850 & 2.10 \\
\hline 13 & 2850 & 3.18 \\
\hline 14 & 2850 & 0.59 \\
\hline 15 & 2850 & 1.28 \\
\hline 16 & 2850 & 0.43 \\
\hline 17 & 2850 & 0.10 \\
\hline 18 & 2850 & 2.86 \\
\hline 19 & 2850 & 2.22 \\
\hline 20 & 2850 & 2.80 \\
\hline 21 & 2850 & 3.90 \\
\hline 22 & 2850 & 4.31 \\
\hline 23 & 2850 & -2.31 \\
\hline 24 & 2850 & 0.00 \\
\hline 25 & 3280 & 0.00 \\
\hline 26 & 3280 & 0.00 \\
\hline 27 & 3300 & 0.00 \\
\hline 28 & 3280 & 0.00 \\
\hline 29 & 2366 & 0.00 \\
\hline 30 & 2780 & 0.00 \\
\hline 31 & 2750 & 0.00 \\
\hline 32 & 2340 & 0.00 \\
\hline 33 & 2920 & 5.95 \\
\hline 34 & 3080 & 0.00 \\
\hline 35 & 2725 & 6.04 \\
\hline 36 & 2513 & 7.15 \\
\hline 37 & 2537 & 0.00 \\
\hline 38 & 2530 & 2.00 \\
\hline 39 & 2654 & 3.43 \\
\hline 40 & 2641 & 4.29 \\
\hline 41 & 2640 & 0.56 \\
\hline 42 & 2655 & 3.44 \\
\hline 43 & 2644 & 4.03 \\
\hline 44 & 2700 & 2.40 \\
\hline 45 & 2630 & 2.78 \\
\hline 46 & 2855 & 0.00 \\
\hline 47 & 2620 & 0.00 \\
\hline 48 & 3040 & 0.00 \\
\hline 49 & 3371 & 0.00 \\
\hline 50 & 2640 & 0.00 \\
\hline 51 & 2720 & 0.00 \\
\hline 52 & 2980 & 0.00 \\
\hline 53 & 3140 & 0.00 \\
\hline 54 & 3390 & 0.00 \\
\hline
\end{tabular}

Figure 3) and negatively (white blocks, Figure 3 ) magnetized 6-km-thick blocks (bodies 6-23, Figure 4) corresponding to normally and reversely magnetized rocks whose magnetizations are listed in Table 1 . The modeling program fit the observed anomalies by varying the magnetizations in the blocks. The sign of the magnetizations is arbitrary and does not indicate whether a block is positively or negatively magnetized. Rather, the blocks are considered positively magnetized if their value is larger than the ones immediately adjacent.

The subsurface structure of the Coast Range Province (bodies 29-34, Figure 4) is not well constrained. Geologic mapping [Walsh et al., 1987] located exposures of Coast Range mafic rocks and sedimentary basins. The sediments the basins represented by bodies 29-32 in Figure 4, were assumed to be nonmagnetic ( $0 \mathrm{~A} / \mathrm{m}$, Table 1$)$; the magnetization of the Coast Range mafic rocks (body 33) was a free parameter. Modeling of the gravity and magnetic lows. relative to the large Coast Range highs (located between distance 480 and $600 \mathrm{~km}$, Figures 3 and 4), determined the basin geometries and that the basin sediments have rela tively low densities $\left(2400-2800 \mathrm{~kg} / \mathrm{m}^{3}\right)$ and range in thickness from 1.6 to $4 \mathrm{~km}$ (bodies 29-30, Figure 4, Table 1).

I divided the rest of the Coast Range Province into two parts (bodies 33 and 34, Figure 4) whose geometries (with the exception of the tops of bodies 23 and 24 which were fixed from seismic refraction data [Taber and Lewis, 1986]) were determined from the modeling of the associated gravity and magnetic highs (Figures 3 and 4). The upper body (33) represents crust, the lower body (body 34), a subduction complex or mantle. I assigned two different densities for body 34,3070 or $3280 \mathrm{~kg} / \mathrm{m}^{3}$ in the starting model, geologically corresponding to subduction complex or mantle, respectively. The $3070 \mathrm{~kg} / \mathrm{m}^{3}$ value is probably a minimum density and, when used in the modeling, yields a maximum boundary of $2920 \mathrm{~kg} / \mathrm{m}^{3}$ on the density of the Coast Range mafic rocks (body 33). A density of $2860 \mathrm{~kg} / \mathrm{m}^{3}$ was obtained for the Coast Range mafic rocks (body 33) when the higher $3280 \mathrm{~kg} / \mathrm{m}^{3}$ density was assigned to body 34 . These densities for the Coast Range mafic rocks (body 33) fall within the $2200-3010 \mathrm{~kg} / \mathrm{cm}^{3}$ range measured from hand samples described above and indicate that the much of upper 15-25 km Coast Range crust is of high density. Geologic mapping [e.g., Tabor and Cady, 1978; Wells, 1981] shows 1-15 km thicknesses of basalts at the surface, and in many places [e.g., Wells, 1981], the basalts are intruded by gabbro and diabase sheets. The $2920 \mathrm{~kg} / \mathrm{m}^{3}$ density is compatible with these rock types and seismic velocities measured in the Oregon Coast Range [Dehlinger et al., 1968; Langston, 1977] and is similar to densities modeled for the core of Mauna Loa, Hawaii, from gravity data [Zucca et al., 1982] and measured for the mostly gabbroic crust in the Bay of Islands ophiolite [Salisbury and Christensen, 1978].

The geometry of the Coast Range mafic rocks, although not well constrained, is compatible with other data. Seismic reflection data from the continental shelf of Washington (Figure 1) indicate that the Coast Range mafic rocks there are about $1 \mathrm{~km}$ thick, underlain by Miocene sediments, and thicken eastward [Snavely, 1987; Snavely and Wagner, 1982]. Magnetotelluric data show that the Coast Range mafic rocks are about $20 \mathrm{~km}$ thick where my model delineates a thickness of about $24 \mathrm{~km}$ (body 33, near $560 \mathrm{~km}$ distance in Figures 3 and 4). At the eastern boundary of the Coast Range mafic rocks, both the magnetotelluric data and my model suggest a thickness of $30 \mathrm{~km}$.

The gravity high over the Coast Range is caused by a combination of several sources: (1) the positive density contrast between the Coast Range mafic rocks (body 33) and the continental shelf sediments to the west (body 5) and the lower density (bodies 35-45) upper $10 \mathrm{~km}$ of the Cascade Range; (2) the positive density contrast between the Coast Range lower crust (body 34) and the continental shetf sediments to the west (body 5) (and with the Cascade Range lower crust (body 48) if the Coast Range lower crust (body 34) is assigned a density of $3280 \mathrm{~kg} / \mathrm{m}^{3}$ ); and (3) the positive 
density contrast between the Coast Range lower crust (body 34) and the Juan de Fuca plate crust (bodies 23 and 24).

The magnetic high over the Coast Range is caused by the mafic rocks (body 33) that are more magnetic than adjacent rock units in the continental slope and Cascade Range. The metization determined by the modeling for the Coast Range mafic rocks (body 33) is $5.9 \mathrm{~A} / \mathrm{m}$, higher than the 2.75 A/m average value obtained from hand samples. In magnetic modeling, there is usually a trade-off between thickness of a body and its magnetization, but thickening body 33 did not reduce the magnetization calculated by the inversion program. Additionally, the calculated thickness of the Coast Range mafic rocks (body 33) is consistent with other data described earlier. The $5.9 \mathrm{~A} / \mathrm{m}$ magnetization value may be a minimum for the Coast Range mafic rocks and is geologically reasonable for oceanic crust and within the range of about 2-8 A/m measured for Pacific seamounts [McNutt, 1986].

The upper crustal section (upper $20 \mathrm{~km}$ ) in the Cascade Range section of the Washington model (Figures 3 and 4, bodies 35-47) is described in detail by Stanley et al. [1987]. The densities and magnetizations in the upper crustal parts of the Washington model, although not well constrained, are compatible with the geologic structures inferred from the MT modeling and are listed in Table 1. Part of the upper 1-4 $\mathrm{km}$ of section consists of Cenozoic basaltic flows and andesitic volcaniclastic rocks and flows (bodies 35-39) with densities ranging from 2200 to $2600 \mathrm{~kg} / \mathrm{m}^{3}$ and magnetizations from 1.7 to $5.4 \mathrm{~A} / \mathrm{m}$ and may be underlain by $5-10 \mathrm{~km}$ of proposed marine sediments (bodies 45 and 47 , called the SWCC sediments (Figure 3)) that may have been part of a prism accreted to the continent in the Eocene [Stanley et al., 1987, 1988]. Part of the gravity low over the Cascade Range (Figure 3 ) is caused by the low densities of these rocks relative to those in the Coast Range. Under Goat Rock Volcano (body 39) is an intrusion (body 44) with a density of $2700 \mathrm{~kg} / \mathrm{m}^{3}$ and a magnetization of $2.4 \mathrm{~A} / \mathrm{m}$ modeled from the gravity and magnetic data [Williams and Finn, 1987].

The modeled midcrustal density of $2930 \mathrm{~kg} / \mathrm{m}^{3}$ for the Washington Cascade Range (body 46) is consistent with seismic velocities measured in the Oregon Cascade Range [Leaver et al., 1984] and can range in value from 2700 to $2930 \mathrm{~kg} / \mathrm{m}^{3}$. The composition of this part of the crust is unknown but is thought to be mafic, possibly oceanic, based on magnetotelluric and seismic [Stanley et al., this issue], as well as geochemical [Leeman et al., 1989; Smith and Leeman, 1987] results. It may be composed of old oceanic crust that was once the leading edge of the North American continent [Armentrout and Suek, 1985] or Coast Range mafic rocks. If the midcrust is composed of Coast Range mafic rocks, they probably would be demagnetized by hydrothermal alteration from magmatism [Connard et al., 1983]. In any case, when the Coast Range mafic rocks are deeper than about $3 \mathrm{~km}$, the positive aeromagnetic anomaly associated with them disappears (see Plate 2 , over the Chehalis Basin (CB), for example), so that the seromagnetic data cannot be used to constrain the composition of rocks as deep as the $15 \mathrm{~km}$ depth of midcrustal block.

I extended the $40 \mathrm{~km}$ Cascades Moho depth [Leaver et al., 1984] west to the eastern edge of the Coast Range basalts, but no information on the actual depth is known there. The density of the Cascade Range mantle (body 49) is modeled to be $3371 \mathrm{~kg} / \mathrm{m}^{3}$, consistent with the $7.9 \mathrm{~km} / \mathrm{s}$ velocities determined in the Oregon Cascades [Leaver et al., 1984] and at the same longitude in Puget Sound [Crosson, 1976 ].
In the Columbia Plateau section of the model, the upper $10-\mathrm{km}$ section consists of basalt flows with interbedded sediments [Stanley, 1984; Catchings and Mooney, 1988]. A compositional "rift pillow" may exist in the lower crust where seismic velocities are higher than normal for continental crust [Catchings and Mooney, 1988]. Much of the observed gravity high (Figure 3 ) is caused by the contrast between the dense rift pillow and the adjacent lower crust and not by the density contrast between the subducting plate and adjacent asthenosphere [Finn, 1988].

\section{Discussion}

\section{Offshore Magnetic Stripe Attenuation}

Scheidegger [1984] explained the magnetic quiet zone offshore Washington as the result of hydrothermal alteration that destroys the magnetic minerals of the magnetic oceanic crust of the subducting Juan de Fuca plate. The modeled magnetizations (Table 1) of the normal (black blocks, Figure 3) and reversed (white blocks, Figure 3) rocks in the dipping part of the Juan de Fuca plate are similar to, if not higher than, those of the plate east of the continental slope, indicating that deepening of the magnetic subducting crust is sufficient to explain attenuation of magnetic stripes and that hydrothermal alteration is not required.

These results can be compared to northern Honshu, Japan, where the magnetic quiet zone is more prominent and broader than off Washington. The magnetic stripes offshore of northern Honshu disappear where the subducting plate reaches a depth greater than about $26 \mathrm{~km}$ [Oshima and Kasuga, 1988]. The Pacific plate is dipping more steeply under Honshu (about $15^{\circ}$ ) than the Juan de Fuca plate is dipping beneath Washington (about $11^{\circ}$ ). Off Washington, the plate does not reach a depth greater than $26 \mathrm{~km}$ until it is under the Coast Range, where its magnetic signature is obscured by that of the Coast Range. This explains why the magnetic stripes, although attenuated, are still observed just offshore Washington (Figure 3 ).

\section{Comparison of Western Washington to Western Oregon and Southern Vancouver Island Structure}

Two-dimensional gravity and magnetic modeling from offshore to onshore over the central Oregon Coast Range [Couch and Braman, 1979; Couch and Pitts, 1980; Couch and Riddihough, 1990] has been done. The modeled densities of the Oregon Coast Range crust [Couch and Bramen, 1979; Couch and Pitts, 1980; Couch and Riddihough, 1990] are lower than those in my Washington model, with the upper $10 \mathrm{~km}$ having an average density of approximately $2650 \mathrm{~kg} / \mathrm{m}^{3}$ and the lower $10-25 \mathrm{~km}$ a density of $2950 \mathrm{~kg} / \mathrm{m}^{3}$ in Oregon (my Washington model shows an average crustal thickness of about $20 \mathrm{~km}$ and a density ranging from 2860 to $2920 \mathrm{~kg} / \mathrm{m}^{3}$ ). In these Oregon models, mantle, rather than subduction complex, is modeled and has a density of $\mathbf{3 3 5 0}$ $\mathrm{kg} / \mathrm{m}^{3}$, higher than the $3075-3280 \mathrm{~kg} / \mathrm{m}^{3}$ values in my Washington model. Decreasing the value for the mantle density would increase the crustal densities in the Oregon models, closer to my Washington value.

MacLeod et al.'s [1977] gravity model in the Washington Coast Range along a north-south profile (approximately at $124^{\circ}$ longitude) from southwest Washington, across the Olympic Mountains, to Vancouver Island shows a crustal 
section comprising low density sediments $\left(2400 \mathrm{~kg} / \mathrm{m}^{3}\right)$ about $3 \mathrm{~km}$ thick, underlain by crust $\left(2700 \mathrm{~kg} / \mathrm{m}^{3}\right) 5 \mathrm{~km}$ thick, a lower crust $\left(2900 \mathrm{~kg} / \mathrm{m}^{3}\right) 12 \mathrm{~km}$ thick, and a mantle $(3280$ $\mathrm{kg} / \mathrm{m}^{3}$ ), similar to that modeled in Oregon. Riddihough [1979] and McClain [1981] modeled the upper $20 \mathrm{~km}$ of Washington Coast Range crust with densities of 2920 and $2900 \mathrm{~kg} / \mathrm{m}^{3}$, respectively, underlain by continental mantle with a density of about $3290 \mathrm{~kg} / \mathrm{m}^{3}$.

All of the models require dense rocks for the upper 15-20 $\mathrm{km}$ of the Coast Range province. The upper bound on the density of the Coast Range mafic rocks is about that of my model of $2920 \mathrm{~kg} / \mathrm{m}^{3}$. The average modeled crustal density for the upper $20 \mathrm{~km}$ of the Oregon Coast Range is about 2800 $\mathrm{kg} / \mathrm{m}^{3}$ [Couch and Pitts, 1980; Couch and Bramen, 1979; Couch and Riddihough, 1990], which may be lower bound on the density of the Coast Range mafic rocks. The density range of $2800-2920 \mathrm{~kg} / \mathrm{m}^{3}$ suggests that the Coast Range mafic rocks are basalts and gabbros with relatively low porosities with only a small component of intermixed sediments.

All of the gravity models require thin (about $20 \mathrm{~km}$ ) crust under the Coast Range. The $20-\mathrm{km}$ crustal thickness characterizes the entire west coast of North America [Couch and Riddihough, 1990; Mooney and Weaver, 1990]. In Oregon, the major modeled change in crustal thickness from about 20 $\mathrm{km}$ to typical continental values of about $40 \mathrm{~km}$ occurs beneath the Willamette Valley and the west flank of the Cascade Range about $180 \mathrm{~km}$ east of the continental slope [Couch and Riddihough, 1990]. In Washington, it occurs about $200 \mathrm{~km}$ east of the continental slope under the Puget Lowlands west of the Cascade Range (Figures 3 and 4).

Under Washington and Oregon, the gravity models alone cannot discriminate between a subduction complex that might be composed of dense mafic and ultramafic rocks [Spence et al., 1985; Clowes et al., 1987] and mantle [Couch and Riddihough, 1990]. However, Riddihough's [1979] and Spence et al.'s [1985] two-dimensional gravity models of Vancouver Island show high-density material $\left(3300 \mathrm{~kg} / \mathrm{m}^{3}\right)$ underlying Vancouver Island crust, possibly related to the proposed subduction complex [Clowes et al., 1987; Couch and Riddihough, 1990]. Similar high-density material was not required for Riddihough's [1979] gravity models of Washington, possibly implying that the subduction complex, if present, has a lower component of mafic and ultramafic rocks than the rocks underlying Vancouver Island. However, my Washington model (Figures 3 and 4) requires that the proposed subduction complex be denser than the trench sediments and therefore that material denser than sediments (like offscraped oceanic crust) also be incorporated within it. Spence et al.'s [1985] gravity model off Vancouver Island also requires that the subduction complex $\left(3280-3300 \mathrm{~kg} / \mathrm{m}^{3}\right)$ be denser than trench sediments $\left(2820 \mathrm{~kg} / \mathrm{m}^{3}\right)$.

Most of the geophysical data for the Oregon, Washington, and Vancouver Island margins suggest that continental mantle is not present under the Coast Range. This has implications for subduction erosion. If the original, preaccretion structure of the Coast Range resembled that of present-day Hawaii, with about $18 \mathrm{~km}$ of basalt and gabbro underlain by mantle [e.g., Zucca et al., 1982], then its present structure results from erosion of its mantle and part of its lower crust. The modeled wedge shape of the Coast Range mafic rocks also suggests that erosion has occurred and that mantle has been replaced with sediments, mafic, and possibly, ultra- mafic rocks, scraped off the subducting plate. The cause of the erosion and offscraping is unknown, but may be related to the buoyancy of the young subducting plate. In other convergent margins, subduction of buoyant oceanic ridges and plateaus, may cause subduction erosion [e.g., Jarrand, 1986; Nur, 1983]. The mechanisms of thinning of the overriding plate may be active abrasion [e.g., Smith, 1976] or frictional heating [Dickinson, 1973] but are difficult to determine.

Acknowledgments. I thank Dal Stanley, Mark Gettings, Ray Wells, and Randy Keller for useful reviews of this manuscript. Ray Wells kindly provided cores from the Coast Range rocks used in the density and magnetization measurements. Discussions with De Stanley, Ray Wells, and Warren Hamilton helped to focus some of the ideas presented here. This work was supported by the Geother. mal Program of the U.S. Geological Survey.

\section{REFERENCES}

Ahrens, T. J., and G. Schubert, Gabbro-eclogite reaction rate and its geophysical significance, Rev. Geophys., 13, 383-400, 1975.

Armentrout, J. M., and D. H. Suek, Hydrocarbon exploration in western Oregon and Washington, AAPG Bull., 69, 627-643, 1985.

Bates, T. G., M. E. Beck, Jr., and R. F. Burmester, Tectosic rotations in the Cascade Range of southern Washington, Geotogy, 9, 184-189, 1982.

Beck, M. E., Jr., Paleomagnetic record of plate margin processes along the western edge of North America, J. Geophys. Res., 84, 7115-7131, 1980.

Blakely, R. J., and R. C. Jachens, Volcanism, isostatic residual gravity, and regional tectonic setting of the Cascade volcanic province, J. Geophys. Res., this issue.

Bromery, R. W., and P. D. Snavely, Jr., Geologic interpretation of reconnaissance gravity and aeromagnetic surveys in northwesteras Oregon, U.S. Geol. Surv. Bull., 1181-N, N1-N13, 1964.

Catchings, R. D., and W. D. Mooney, Crustal structure of the Columbia Plateau: Evidence for continental rifting, J. Geophys. Res., 93, 459-474, 1988.

Clowes, R. M., M. T. Brandon, A. G. Green, C. J. Yorath, A. Sutherland-Brown, E. R. Kanasewich, and C. Spencer, LITHOPROBE-Southern Vancouver Island, Can. J. Earth Sci., 24, 31-51, 1987.

Committee for the Magnetic Anomaly Map of North America, Magnetic anomaly map of North America, 4 sheets, scalc 1:5,000,000, Geol. Soc. of Am., Boulder, Colo., 1987.

Connard, G., R. W. Couch, G. Ness, and S. Troseth, Magnetic anomaly identifications, in Western North America Continental Margin and Adjacent Ocean Floor off Oregon and Washingtow. Atlas 1, Ocean Margin Drilling Program Regional Atlas Series, edited by L. D. Kulm et al., sheet 5, Marine Science Intern tional, Woods Hole, Mass., 1984.

Connard, G., R. Couch, and M. Gemperle, Analysis of aerome netic measurements from the Cascade Range in central Oregon, Geophysics, 48, 376-390, 1983.

Couch, R. W., and D. Braman, Geology of the continental margin near Florence, Oregon, Oreg. Geol., 41, 171-179, 1979.

Couch, R. W., and G. S. Pitts, The structure of the continentel margin near Coos Bay, Oregon, in Prospects for oil and gas in The Coos Basin, Western Coos, Douglas, and Lane Counties, Ore gon, Oil Gas Invest. 6 , edited by V. C. Newton, pp. 23-26, Oregon Department of Geology and Mineral Industries, Portland, 1980.

Couch, R. W., and R. P. Riddihough, The crustal structure of the western continental margin of North America, The Geophysical Framework of the Continental United States, edited by L.C. Pakiser and W. D. Mooney, Mem. Geol. Soc. Am., 103-128, 1990.

Couch, R., and S. Woodcock, Gravity and structure of the conth nental margins of southwestern Mexico and northwestern Gutemala, J. Geophys. Res., 86, 1829-1840, 1981.

Cox, A., and R. R. Doell, Review of paleomagnetism, Geal. Sac. Am. Bull., 71, 645-768, 1960. 
Crosson, R. S., Crustal structure modelling of earthquake data, 1, Simultaneous least squares estimation of hypocenter velocity parameters, J. Geophys. Res., 81, 3036-3046, $1976 a$.

Crosson, R. S., Crustal structure modelling of earthquake data, 2, Velocity structure of the Puget Sound region, J. Geophys. Res., 81, 3047-3054, 19766 .

Crosson, R. S., and T. J. Owens, Slab geometry of the Cascadia subduction zone beneath Washington from earthquake hypocenters and teleseismic converted waves, Geophys. Res. Lett., 14. 824-827, 1987

Dehlinger, P., R. W. Couch, and M. Gemperle, Continental and oceanic structure from the Oregon coast westward across the Juan de Fuca Ridge, Can. J. Earth Sci., 5, 1079-1090, 1968.

Dickinson, W. R., Widths of modern arc-trench gaps proportional to past duration of igneous activity in associated magmatic arcs, $J$. Geophys. Res., 78, 3376-3389, 1973.

Duncan, R. A., A captured island chain in the Coast Range of Oregon and Washington, J. Geophys. Res., 87, 10,827-10,837, 1982.

Evarts, R. C., R. P. Ashley, and J. G. Smith, Geology of the Mount St. Helens area: Record of discontinuous volcanic and plutonic activity in the Cascade Arc of southern Washington, J. Geophys. Res., 92, 10,155-10,169, 1987.

Finn, C., Description of magnetic tape containing Washington State gravity anomaly data, Rep. USGS-GD-85-001, Natl. Tech. Inf. Serv., Springfield, Va., 1984.

Finn, C., Structure of the convergent Washington margin, implications for other subduction zones and for continental growth processes, Ph.D. dissertation, 146 pp., Univ. of Colo., Boulder, 1988.

Fukao, Y., A. Yamamoto, and M. Kono, Gravity anomaly across the Peruvian Andes, J. Geophys. Res., 94, 3867-3890, 1989.

Grow, J., Crustal and mantle structure of the central Aleutian arch, Geol. Soc. Am. Bull., 84, 2169-2192, 1973.

Grow, J., and C. Bowin, Evidence for high density crust and mantle beneath the Chile trench due to the descending lithosphere, $J$. Geophys, Res., 80, 1449-1458, 1975.

Guffanti, M., and C. S. Weaver, Distribution of volcanic vents in the Cascade Range: Volcanic are segmentation and regional tectonic considerations, J. Geophys. Res., 93, 6513-6529, 1988.

Hall, J. B., and K. L. Othberg, Thickness of unconsolidated sedimeats, Puget Lowlands Washington, Geol. Map GM-12, State of Wash., Dep. of Nat. Resour., Div. of Geol. and Earth Resour., Olympia, 1974.

Hamilton, E. L., Sound velocity-density relations in sea-floor sediments and rocks, J. Acoust. Soc. Am., 63, 366-377, 1978.

Ise, F. T., Washington and Oregon-Are there other rocks to explore?, Oil Gas J., 12, 112-115, 1985.

Jarrard, R. D., Relations among subduction parameters, Rev. Geophys., 24, 217-284, 1986.

Keach, R. W., II, J. E. Oliver, L. D. Brown, and S. Kaufman, Cenozoic active margin and shallow Cascades structure: $\mathrm{CO}$ CORP results from westem Oregon, Geol. Soc. Am. Bull., 101, 783-794, 1989.

King, P. B., and H. M. Beikman, Geologic map of the United States, scale 1:2,500,000, U.S. Geol. Surv., Reston, Va., 1974.

Langston, C. A., Corvallis, Oregon, crustal and upper mantle receiver structure from teleseismic $\boldsymbol{P}$ and $S$ waves, Bull. Seismol. Soc. Am., 67, 713-724, 1977.

Leaver, D. S., W. D. Mooney, and W. M. Kohler, A seismic refraction study of the Oregon Cascades, J. Geophys. Res., 89, 3121-3134, 1984.

Leeman, W. P., D. R. Smith, W. Hildreth, Z. Palacz, and N. Rogers, Compositional diversity of the late Cenozoic basalts in a transect across the southern Washington Cascades: Implications for subduction zone magmatism, Geological, Geophysical, and Tectonic Setting of the Cascade Range, Workshop XLIV, U.S. Geol. Surv. Open File Rep., 89-178, 318-350, 1989.

MacLeod, N. S., D. L. Tiffin, P. D. Snavely, Jr., and R. G. Currie Geologic interpretation of magnetic and gravity anomalies in the Strait of Juan de Fuca, U.S.-Canada, Can. J. Earth. Sci., I4, 223-238, 1977.

Magill, J. R., A. Cox, and R. Duncan, Tillamook Volcanic Series: Further evidence for tectonic rotation of the Oregon Coast Range, J. Geophys. Res., 86, 2953-2970, 1981.

Messey, N. W. D., Metchosin Igneous Complex, southern Vancou- ver Island: Ophiolite stratigraphy developed in an emergent island setting, Geology, 14, 602-605, 1986.

McClain, K. J., A geophysical study of accretionary processes on the Washington continental margin, Ph.D. thesis, Univ. of Wash., Seattle. 1981.

McClain, K. J., and J. J. Taber, Regional Seismic Refraction, in Western North American Continental Margin and Adjacent Ocean Floor off Oregon and Washington, Atlas 1 , Ocean Margin Drilling Program Regional Atlas Series, edited by L. D. Kulm, sheet 9, Marine Science International, Woods Hole, Mass., 1984.

McNutt, M. K., Nonuniform magnetization of seamounts: A least squares approach, J. Geophys. Res., 91, 3686-3700, 1986.

Michaelson, C. A., and C. S. Weaver, Upper mantle structure from teleseismic $P$ wave arrivals in Washington and northern Oregon, J. Geophys. Res., 91, 2077-2094, 1986.

Mooney, W. D., and C. S. Weaver, Regional crustal structure and tectonics of the Pacific coastal states: Califomia, Oregon, and Washington, The Geophysical Framework of the Continental United States, edited by L. C. Pakiser and W. D. Mooney, Mem. Geol. Soc. Am., 129-162, 1990.

Nafe, J. E., and C. L. Drake, Variation with depth in shallow and deep water marine sediments of porosity, density and the velocities of compressional and shear waves, Geophysics, 22, 523-552, 1957.

Nur, A., Accreted terranes, Rev. Geophys., 21, 1779-1785, 1983.

Oshima, S., and S. Kasuga, Geomagnetic estimation of the depth of the subducting plate in northeast Japan, J. Geomagn. Geoelectr., 40, 465-483, 1988.

Peddie, N. W., The 1985 magnetic model for the United States (abstract), Eos Trans. AGU, 68, 530, 1987.

Rasmussen, J., and E. Humphreys, Tomographic image of the Juan de Fuca plate beneath Washington and western Oregon using teleseismic $P$-wave travel times, Geophys. Res. Lett., IS, 1417$1420,1988$.

Rau, W., Geology of the Washington coast between Point Grenville and the Hoh River, Bull. Wash. Div. Geol. Earth Resour., 66, 58 pp., 1973.

Riddihough, R. P., A model for recent plate interactions off Canada's west coast, Can J. Earth Sci., 14, 384-396, 1977.

Riddihough, R. P., Gravity and structure of an active marginBritish Columbia and Washington, Can. J. Earth Sci., 16, 350$363,1979$.

Riddihough, R. P., Recent movements of the Juan de Fuca plate system, J. Geophys. Res., 89, 6980-6994, 1984.

Salisbury, M. H., and N. I. Christensen, The seismic velocity of a traverse through the Bay of Islands ophiolite complex, Newfoundland, an exposure of oceanic crust and upper mantle, $J$. Geophys. Res., 83, 805-817, 1978.

Scheidegger, K. F., Thermal evolution of the Juan de Fuca plate, in Western North American Continental Margin and Adjacent Ocean Floor off Oregon and Washington, Atlas $I$, Ocean Margin Drilling Program Regional Atlas Series, edited by L. D. Kulm et al., sheet 8, Marine Science International, Woods Hole, Mass., 1984.

Segawa, J., and Y. Tomoda, Gravity measurements near Japan and study of the upper mantle beneath the oceanic trench-Marginal sea transitional zones, in The Geophysics of the Pacific Ocean Basin and Its Margin, Geophys. Monogr. Ser., vol. 19, edited by G. H. Sutton, M. H. Manghnani, and R. Moberly, pp. 35-52, AGU, Washington, D. C., 1976.

Sherrod, D. R., and J. G. Smith, Quaternary extrusion rates from the Cascade Range, northwestern United States and southern British Columbia, J. Geophys. Res., this issue.

Shor, G. G., P. Dehlinger, H. K. Kirk, and W. S. French, Seismic refraction studies off Oregon and northern California, J. Geophys. Res., 73, 2175-2194, 1968.

Simpson, R. W., R. C. Jachens, R. J. Blakely, and R. W. Saltus, A new isostatic residual gravity map of the coterminus United States with a discussion on the significance of isostatic residual anomalies, J. Geophys. Res., 91, 8348-8372, 1986.

Smith, A. G., Plate tectonics and orogeny: A review, Tectonophysics, 33, 215-285, 1976

Smith, D. R., and W. P. Leeman, Petrogenesis of Mount St. Helens dacitic magmas, J. Geophys. Res., 92, 10,313-10,334, 1987.

Smith, J. G., Geologic map of Upper Eocene to Holocene volcanic 
and related rocks in the Cascade Range, Washington, U.S. Geol. Surv. Misc. Field Stud. Map, in press, 1990.

Snavely, P. D., Tertiary geologic framework, neotectonic, and petroleum potential of the Oregon-Washington continental margin, in Geology and Resource Potential of the Continental Margin of North America and Adjacent Ocean Basins: Beaufort Sea to Baja California, Earth Sci. Ser., vol. 6, edited by D. W. Scholl, A. Grantz, and J. G. Vedder, pp. 305-335. Circum-Pacific Council for Energy and Mineral Resources, Houston, Tex., 1987.

Snavely, P. D., Jr., and E. M. Baldwin, Siletz River volcanic series, northwestern Oregon, AAPG Bull., 32, 806-812, 1948.

Snavely, P. D., Jr., and N. S. MacLeod, Yachats basalts-An upper Eocene differentiated volcanic sequence in the Oregon Coast Range, J. Res. U.S. Geol. Surv., 2, 395-403, 1974.

Snavely, P. D., Jr., and H. C. Wagner, Geologic cross section across the continental margin of southwestern Washington, U.S. Geol. Surv. Open File Rep., 82-459, 10 pp., 1982.

Snavely, P. D., Jr., R. D. Brown, Jr., A. E. Roberts, and W. W. Rau, Geology and coal resources of the Centralia-Chehalis district Washington, U.S. Geol. Surv. Bull., 1053, 159 pp., 1958.

Spence, G. D., R. M. Clowes, and R. M. Ellis, Seismic structure across the active subduction zone of western Canada, J. Geophys. Res., 90, 6754-6772, 1985.

Stanley, W. D., Tectonic study of the Cascade Range and Columbia Plateau in Washington state based on magnetotelluric soundings, J. Geophys. Res., 89, 4447-4460, 1984.

Stanley, W. D., C. A. Finn, and J. L. Plesha, Tectonics and conductivity structures in the southern Washington Cascades, $J$. Geophys. Res., 92, 10,179-10,193, 1987.

Stanley, W. D., W. Heran, and C. A. Finn, A major Eocene suture in the southwestern Washington Cascades: Are hydrocarbon source rocks buried beneath volcanic flows?, paper presented at 1988 McKelvey Forum on Energy Resources, U.S. Geol. Surv., Denver, Colo., 1988.

Stanley, W. D., W. D. Mooney, and G. S. Fuis, Deep crustal structure of the Cascade Range and surrounding regions from seismic refraction and magnetotelluric data, J. Geophys. Res., this issue.

Stuart, D. J., Gravity study of the crustal structure in western Washington, U.S. Geol. Surv. Prof. Pap., 424-C, C273-C276, 1961

Taber, J. J., and B. T. R. Lewis, Crustal structure of the Washington continental margin from refraction data, Bull. Seismol. Soc. Am., 76, 1011-1024, 1986.

Taber, J. J., and S. S. Smith, Seismicity and focal mechanisms associated with the subduction of the Juan de Fuca plate beneath the Olympic Peninsula, Washington, Bull. Seismol. Soc. Am., 75, 237-249, 1985.

Tabor, R. W., and W. M. Cady, The structure of the Olympic Mountains, Washington: Analysis of a subduction zone, U.S. Geol. Surv. Prof. Pap., 1033, 1978.

Telford, W. M., L. P. Geldart, R. E. Sheriff, and D. A. Keys, Applied Geophysics, 860 pp., Cambridge University Press, New York, 1976.

Turcotte, D. L., and G. Schubert, Geodynamics, in Applications of Continuum Physics to Geological Problems, pp. 164-165, John Wiley, New York, 1982.
Walsh, T. J., M. A. Korosec, W. M. Phillips, R. L. Logan, and H. W. Schasse, Geologic map of Washington-southwest gead rant, Geol. Map G-34, 2 sheets, scale 1:250,000, Wash. Div. of Geol. and Earth Resour., Olympia, 1987.

Wannamaker, P. E., J. R. Booker, A. G. Jones, S. D. Chave, J. H. Filloux, H. S. Waff, and L. K. Law, Resistivity cross section through the Juan de Fuca subduction system and its tectonic implications, J. Geophys. Res., 94, 14,127-14,144, 1989.

Watts, A. B., and M. Talwani, Gravity effects of downgoing lithospheric slabs beneath island arcs, Geol. Soc. Am. Bull., 86, 1-4, 1975.

Weaver, C. S., and G. E. Baker, Geometry of the Juan de Fuca plate beneath Washington and northem Oregon from seismicity, Bull. Seismol. Soc. Am., 78, 264-275, 1988.

Webring, M., SAKI: A FORTRAN program for generalized inversion of gravity and magnetic profiles, U.S. Geol. Surv. Open Fite Rep., 85-112, 104 pp., 1985.

Wells, R. E., Geologic map of the eastern Willapa Hills, Cowhtz, Lewis, Pacific, and Wahkiakum counties, Washington, U.S. Geol. Surv. Open File Rep., 81-674, 1981.

Wells, R. E., Geologic map of the Cape Disappointment-Nasele River area, Pacific County, scale 1:62,500, Washington, U.S. Geol. Surv. Misc. Invest. Map, 1832, 1989.

Wells, R. E. and R. S. Coe, Paleomagnetism and geology of Eocene volcanic rocks of southwest Washington: Implications for mectanisms of tectonic rotation, J. Geophys. Res., 90, 1925-1948, 1985.

Wells, R. E., D. C. Engebretson, P. D. Snavely, Jr., and R. S. Coe, Cenozoic plate motions and the volcano-tectonic evolution of western Oregon and Washington, Tectonics, 3, 275-294, 1984.

Wetten, J. T., R. E. Zartman, R. J. Blakely, and D. L. Jomes, Allochthanous Jurassic ophiolite in northwest Washington, Geol. Soc. Am. Bull., 91, part 1, 359-368, 1980.

Williams, D. L., and C. Finn, Analysis of gravity data in volcanic terrain and gravity anomalies and subvolcanic intrusions in the Cascade Range, U.S.A. and at other selected volcanoes, in the Utility of Gravity and Magnetic Maps, edited by W. Hinze, pp. 361-374, Society of Exploration Geophysicists, Tulsa, Otke. 1985.

Williams, D. L., and C. Finn, Evidence for a shallow pluton beneath Goat Rocks Wilderness, Washington, from gravity and mageetic data, J. Geophys. Res., 92, 4867-4880, 1987.

Williams, D. L., G. Abrams, C. Finn, D. Dzurisin, D. J. Jobnson, and $\mathbf{R}$. Denlinger, Evidence from gravity data for an intrusive complex beneath Mount St. Helens, J. Geophys. Res., 92, 10,207$10,222,1987$.

Zucca, J. J., D. P. Hill, and R. L. Kovach, Crustal structure of Mauna Loa Volcano, Hawaii, from seismic refraction and gravity data, Bull. Seismol. Soc. Am., 72, 1535-1550, 1982.

C. Finn, U.S. Geological Survey, MS 964, P. O. Box 25046, Denver Federal Center, Denver, CO 80225.

(Received August 30, 1989; revised March 28, 1990; accepted April 23, 1990.) 